\title{
Distribution and accumulation of heavy metals in some tissues of three endemic wild fish species in Dianchi Lake, China
}

\author{
Xiangqi Menga ${ }^{a}$, Qiang Li, Dong Ren, Yang Liu, Bin Huang, Xuejun Pan*b \\ Faculty of Environmental Science and Engineering, Kunming University of Science and \\ Technology, Kunming, Yunnan 650500, PR China \\ a869704537@qq.com, ${ }^{\mathrm{b}}$ xjpan@kmust.edu.cn
}

Keywords: Heavy metals, Dianchi Lake, Endemic wild fish species, Some tissues.

Abstract. The present paper dealt with the concentrations and bioaccumulation of heavy metals $(\mathrm{Pb}$, $\mathrm{Zn}, \mathrm{Cu}, \mathrm{Cd}, \mathrm{Cr}$ ) in three endemic wild fish in Dianchi Lake, China. The mean concentration in fish organ tissues (head, scale and skin) does not have an obvious ordering. This showed that the metal concentrations of $\mathrm{Pb}, \mathrm{Zn}, \mathrm{Cu}, \mathrm{Cd}$ and $\mathrm{Cr}$ in all collected fish species didn't exceeded those standards by Ministry of Health of the People's Republic of China (GB 2762-2012). The present level observed in fish species is safe for human consumption from this lake.

\section{Introduction}

Geochemical structure, mining activity, metal smelt-ing, industrial wastes, incineration of waste and ur-ban sewage discharge create a potential source of heavy metal pollution in the water bodies[1]. Heavy metals are deposited, assimilated or incorporated in water, sediment and aquatic animals since they geo-chemistry cannot be degraded ${ }^{[2]}$. They also can ac-cumulate in food chain and become toxic to humans once reach threshold bioavailable levels ${ }^{[3]}$. The lakes have received considerable loads of pollutants due to industrialization in city.

Heavy metals like copper and zinc are essential for fish metabolism while some others such as cadmium and lead have no known role in biological systems. Fish are not only long living and absorb a variety of pollutants over time but also normally occupy high positions in aquatic trophic webs, so they can be used as a biomonitor for heavy metal contamination ${ }^{[4,5]}$. Heavy metal pollution is accumulated in fish then possibly transferred to humans through the food chain. Heavy metals can be classified as toxic (e.g. lead, cadmium, chromium) and essential (e.g. copper, zinc) for living organisms, but even the essential metals are toxic at higher concentrations ${ }^{[6]}$. For this reason, in order to evaluate the possible potential risks to human health of fish consumption, it is extremely important to determine contents of heavy metals in fish ${ }^{[7]}$. The study of heavy metal accumulated in fish tissues (head, scale and skin) is therefore of interest in assessing pollution in natural bodies of water. These tissues in fish are chosen for these reasons, (1) the head is a key organ in the metabolism and storage of metals, (2) the scale and skin reflect the metal levels in the water since they are in direct contact. When the head was included in the study, the gills must be cut off.

Dianchi Lake (centered around $24^{\circ} 48^{\prime} \quad 02^{\prime \prime} \mathrm{N}, 102^{\circ} 40^{\prime} 17^{\prime \prime} \mathrm{E}$ ) is located in the southwest of China. The soil of the basin is mainly of the type of red soil and paddy soil, with a vegetation coverage rate of $21 \%$. It is a shallow freshwater plateau lake and the average and maximum water depth of the lake are $4.4 \mathrm{~m}$ and $10.4 \mathrm{~m}$, respectively. During several decades of rapid economic development, the lake has been seriously polluted by wastewaters and wastes from industry, agriculture and daily life. Heavy metal pollution has made high environmental pressure in this lake. The lake has a weak alkaline environment and higher dissolved oxygen concentration (reflected by redox potential levels). Under weak alkaline condition, minimal metal release from sediments is observed even with considerable physical disturbance ${ }^{[8,9]}$. Therefore, the heavy metal con-centration in sediment was higher than that in surface water.

The present study compared the concentrations of $\mathrm{Pb}, \mathrm{Zn}, \mathrm{Cu}, \mathrm{Cd}$ and $\mathrm{Cr}$ in three endemic wild fish species (Cyprinus carpio, Carassius auratus and Anabarilius alburnops) in Dianchi Lake. It should be noted that these fish species are considered to be an essential part of the diet in this region. The 
objective of this study is to provide human health risk information associated with fish consumption in this region. The information could be used as a contribution to the knowledge and rational management of this region in the future.

\section{Material and methods}

Study area and fish samples collection. The study areas and sampling sites are shown in Fig. 1.

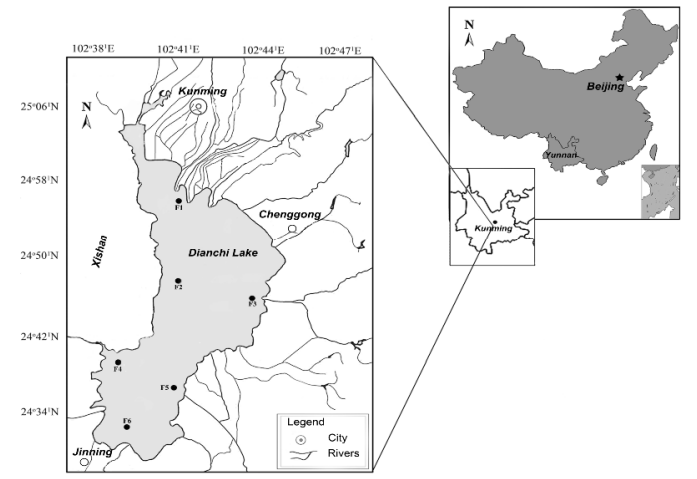

Fig.1 Map of fish sampling locations in Dianchi Lake, China

The $\Delta$ represents the locations of the fish sample collection. F1: Huiwan, F2: The west of Guanyinshan, F3:

Dayuxiang F4: The west of Haikou, F5: Baiyu, F6: The south of Dianchi

Fish samples were collected from local fishermen in 6 sites across the lake, who had been interviewed to ensure that the species were caught in the area of interest for this study. Since these fish were not caged, samples from a particular "site" actually represent a segment of water that may range approximately $3 \mathrm{~km}$ from the sampling location.

Fish species selected for analysis were based on several considerations including availability at sampling sites, size (weight), migratory behavior, and placement in the food chain ${ }^{[10]}$. Since the fish species represented an area within a lake, less migratory species were preferred ${ }^{[11]}$. Fish species analysis included carp, crucian carp and silvery minnow, which were common in Dianchi Lake and placed in the same position in the food chain. The three fish species were widely consumed as food for local communities around Dianchi Lake which were caught with nets from the Dianchi Lake in the open season. Fishes were immediately placed in coolers with ice and carried to the laboratory for sample preparation.

Chemicals and apparatus. All solvents used in this study were of analytical pure grade or chromatographic pure grade. The stock standard solutions $(1,000 \mu \mathrm{g} / \mathrm{ml})$ of $\mathrm{Pb}, \mathrm{Zn}, \mathrm{Cu}, \mathrm{Cd}$ and $\mathrm{Cr}$ were used and solutions for standard curve preparation were made by appropriate dilution prior to use. All the plastic containers and glassware were soaked in dilute nitric acid (10\%) and rinsed with distilled water before use. Microwave-assisted digestion (MAD) was performed by ETHOS 1 advanced microwave digestion system (Milestone, Italy) equipped with a 12-sample tray and temperature control system. A flame/graphite atomic absorption spectrometer (AAS, Varian Instruments AA240) was used for sample analysis in this study.

Sample preparation and analysis. Fish were killed in a lethal dose of anaesthetic (MS-222) and dissected with a clean scalpel blade to separate the tissues from the bones. Each organ tissue of some individuals were dissected, pooled, homogenised and freeze-dried (Eyela FDU-1200, Japan) for four days. Each organ tissue was homogenised and kept separately. Due to their small size $(<15 \mathrm{~cm})$, no single skin has been identified, only separate the head and scale organs of silvery minnows. After lyophilisation, the samples were ground to powder and sieved to $<1 \mathrm{~mm}$ and then stored in sealed plastic pack at room temperature until digestion. $1 \mathrm{~g}$ dry fish samples were digested with $6 \mathrm{ml}$ of concentrated $\mathrm{HNO}_{3}(65 \%)$ and $2 \mathrm{ml}$ of $\mathrm{H}_{2} \mathrm{O}_{2}(30 \%)$ in microwave digestion system and diluted to $10 \mathrm{ml}$ with double deionized water (Milli-Q $18.2 \mathrm{M} / \mathrm{cm}$ resistivity). The digestion conditions for microwave system were applied as $2 \mathrm{~min}$ for $250 \mathrm{~W}, 2 \mathrm{~min}$ for $0 \mathrm{~W}, 6 \mathrm{~min}$ for $250 \mathrm{~W}, 5 \mathrm{~min}$ for $400 \mathrm{~W}, 8 \mathrm{~min}$ for $550 \mathrm{~W}$, vent: $8 \mathrm{~min}$, respectively ${ }^{[12]}$. A blank digest was carried out in the same way. 
$\mathrm{Pb}, \mathrm{Zn}, \mathrm{Cu} \mathrm{Cd}$ and $\mathrm{Cr}$ levels in the fish tissues were measured by a flame/graphite atomic absorption spectrometer (AAS, Varian Instruments AA240).

\section{Results and discussion}

Fish analysis. The concentrations of heavy metals in fish head, scale and skin are shown in Fig. 2. The concentrations of all metals analyzed in endemic wild fish species differed significantly between locations, tissues and significantly negative between species. All metal concentrations were determined on a dry weight basis. Compared to other sites, the three fish species at site F4 and F5, which was the closest site to Jinning industrial park, have significantly higher concentrations of $\mathrm{Cu}, \mathrm{Cd}$ and $\mathrm{Cr}(\mathrm{p}<$ $0.05)$ in fish head. Similarly, concentrations of $\mathrm{Pb}$ in fish head was much higher $(\mathrm{p}<0.05)$ at sites F3 and F4 compared to the other sites. In addition, metal concentration of $\mathrm{Zn}$ in fish head has not changed much in each site.

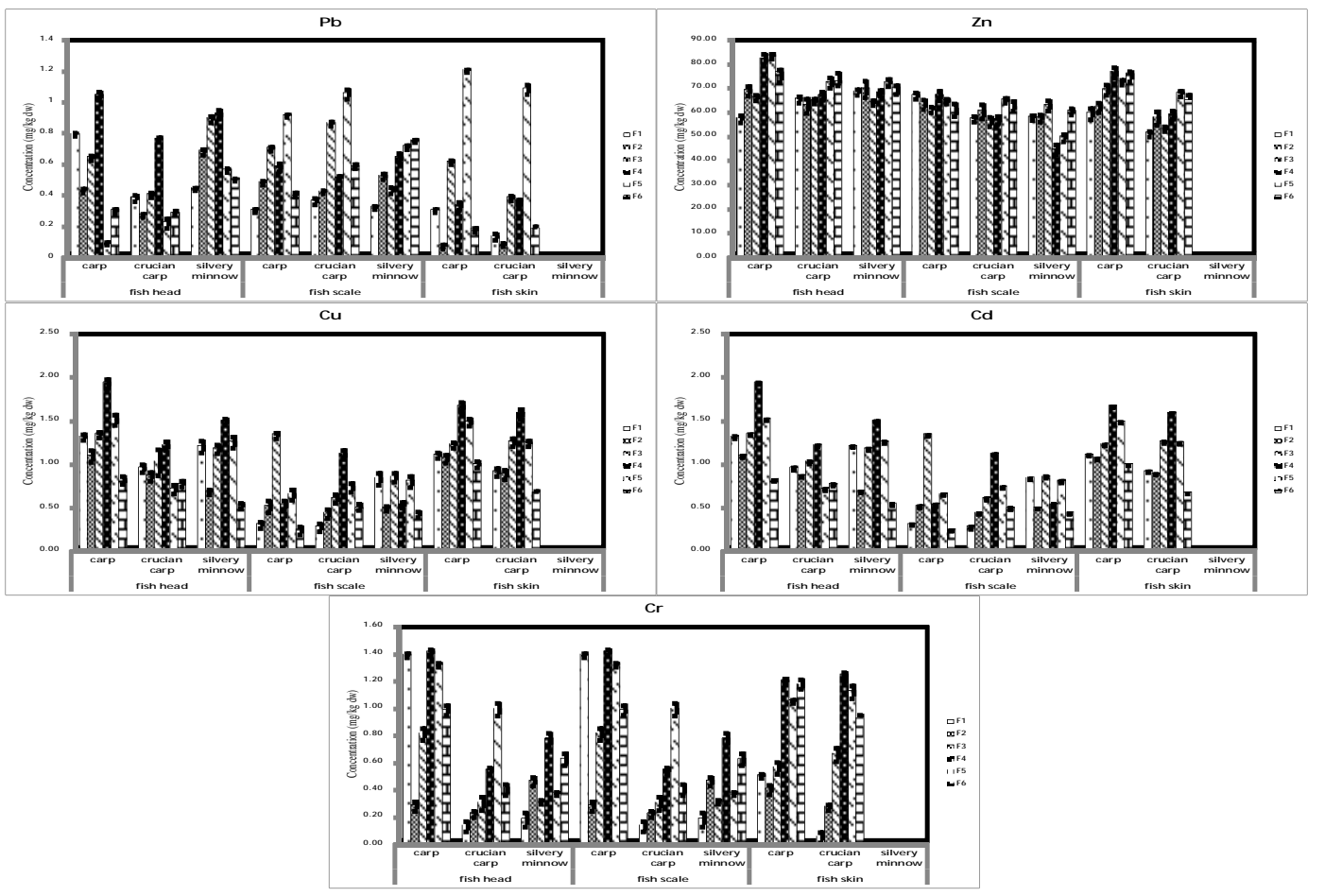

Fig. 2 Concentrations of $\mathrm{Pb}, \mathrm{Zn}, \mathrm{Cu}, \mathrm{Cd}$ and $\mathrm{Cr}$ in fish samples collected from Dianchi Lake

The lowest and highest $\mathrm{Pb}$ levels found were $0.07 \pm 0.005 \mathrm{mg} / \mathrm{kg}$ in carp at site $\mathrm{F} 2$ and $1.20 \pm 0.01$ $\mathrm{mg} / \mathrm{kg}$ in fish skin of carp at site F5, respectively. $\mathrm{Pb}$ is known to induce increased blood pressure and cardiovascular disease in adults and reduced intellectual performance and cognitive development in children $^{[13]}$. $\mathrm{Zn}$ and $\mathrm{Cu}$ concentrations were comparatively higher than the other metals in muscles for all the species studied in the present investigation, and the value of $\mathrm{Zn}$ in fish head, scale and skin have not changed much in each site. $\mathrm{Zn}$ and $\mathrm{Cu}$ is the essential elements but very high intake can cause adverse health problems such as liver and kidney damage ${ }^{[14]}$. Cd concentrations were comparatively lower in muscles for all the species studied. The concentrations of $\mathrm{Cd}$ in the three endemic wild fish species at site F4 were higher than the values at other sites. To some degree, industrial effluents contributed to the $\mathrm{Cd}$ pollution in this area, which was the closest site to Jinning industrial park. The lowest and highest Cr levels found in three species were $0.13 \pm 0.007 \mathrm{mg} / \mathrm{kg}$ and $1.41 \pm 0.09 \mathrm{mg} / \mathrm{kg}$ in carp head, respectively. Cr is an essential mineral in humans and has been related to carbohydrate, lipid, and protein metabolism ${ }^{[15]}$.

Based on the national food safety standard (GB 2762-2012), the tolerance limit of zinc (GB 13106-91) and the tolerance limit of copper (GB 15199-94) in food were presented as concentrations per unit wet weight of the samples. The $\mathrm{Pb}, \mathrm{Cd}$ and $\mathrm{Cr}$ values of threshold established by national food safety standard were $0.5 \mathrm{mg} / \mathrm{kg} \mathrm{ww}, 0.1 \mathrm{mg} / \mathrm{kg}$ ww and $2.0 \mathrm{mg} / \mathrm{kg}$ ww and the tolerance limit of zinc and copper in food are $50 \mathrm{mg} / \mathrm{kg} \mathrm{ww}, 10 \mathrm{mg} / \mathrm{kg} \mathrm{ww}$. Water contents of the analyzed fish are 82.5 $86 \%$ in the current study. This showed that the metal concentrations of $\mathrm{Pb}, \mathrm{Zn}, \mathrm{Cu}, \mathrm{Cd}$ and $\mathrm{Cr}$ in all 
collected fish species didn't exceeded those standards by Ministry of Health of the People's Republic of China (GB 2762-2012). The present level observed in fish species is safe for human consumption from this lake.

\section{Conclusions}

The present study shows the levels of metal accumulation in three endemic wild fish species. The mean concentration in fish organ tissues (head, scale and skin) does not have an obvious ordering. This showed that the metal concentrations of $\mathrm{Pb}, \mathrm{Zn}, \mathrm{Cu}, \mathrm{Cd}$ and $\mathrm{Cr}$ in all collected fish species didn't exceeded those standards by Ministry of Health of the People's Republic of China (GB 2762-2012). The present level observed in fish species is safe for human consumption from this lake. It was concluded that people were not subjected to a significant potential health risk from the intake of a single metal consumed in fish. Furthermore, fish is a kind of nutritious food which should not be omitted from a balanced diet. Human health risks associated with fish consumption were not negligible, and the sources of heavy metal pollution in fish clearly should be controlled. In a word, proper management is indispensable to sustain the quality of the lake for the coming generations.

\section{Acknowledgements}

This project was sponsored by the Applied Basic Research Key Project of Yunnan, China (Grant No. 2013FA011).

\section{References}

[1] Yang H, Rose N. Trace element pollution records in some UK lake sediments, their history, influence factors and regional differences [J]. Environment international, 2005, 31(1): 63-75.

[2] Malik N, Biswas A K, Qureshi T A, et al. Bioaccumulation of heavy metals in fish tissues of a freshwater lake of Bhopal [J]. Environmental monitoring and assessment, 2010, 160(1-4): 267-76.

[3] Wright D, Mason R. Biological and chemical influences on trace metal toxicity and bioaccumulation in the marine and estuarine environment $[\mathrm{J}]$. International Journal of Environment and Pollution, 2000, 13(1-6): 226-48.

[4] Hofer R, Lackner R, Kargl J, et al. Organochlorine and metal accumulation in fish (Phoxinus phoxinus) along a north-south transect in the Alps [J]. Water, Air, and Soil Pollution, 2001, 125(1): 189-200.

[5] Liu F, Ni H-G, Chen F, et al. Metal accumulation in the tissues of grass carps (Ctenopharyngodon idellus) from fresh water around a copper mine in Southeast China [J]. Environmental monitoring and assessment, 2012, 184(7): 4289-99.

[6] Ebdon L. Trace element speciation for environment, food and health [M]. Royal Society of Chemistry, 2001.

[7] Dural M, Göksu M Z L, Özak A A. Investigation of heavy metal levels in economically important fish species captured from the Tuzla lagoon [J]. Food Chemistry, 2007, 102(1): 415-21.

[8] Du L-N, Li Y, Chen X-Y, et al. Effect of eutrophication on molluscan community composition in the Lake Dianchi (China, Yunnan) [J]. Limnologica - Ecology and Management of Inland Waters, 2011, 41(3): 213-9.

[9] Atkinson C A, Jolley D F, Simpson S L. Effect of overlying water pH, dissolved oxygen, salinity and sediment disturbances on metal release and sequestration from metal contaminated marine sediments [J]. Chemosphere, 2007, 69(9): 1428-37.

[10] Keith T L, Snyder S A, Naylor C G, et al. Identification and quantitation of nonylphenol ethoxylates and nonylphenol in fish tissues from Michigan [J]. Environmental science \& technology, 2001, 35(1): 10-3. 
[11] Liu J, Wang R, Huang B, et al. Distribution and bioaccumulation of steroidal and phenolic endocrine disrupting chemicals in wild fish species from Dianchi Lake, China [J]. Environmental pollution, 2011, 159(10): 2815-22.

[12] Tuzen M. Toxic and essential trace elemental contents in fish species from the Black Sea, Turkey $[\mathrm{J}]$. Food and chemical toxicology : an international journal published for the British Industrial Biological Research Association, 2009, 47(8): 1785-90.

[13] Commission E, No R. 2006 of 19 December 2006, Setting Maximum Levels for certain Contaminants in Foodstuffs [J]. Official Journal of the European Union, 2006,

[14] Ikem A, Egiebor N O. Assessment of trace elements in canned fishes (mackerel, tuna, salmon, sardines and herrings) marketed in Georgia and Alabama (United States of America) [J]. Journal of food composition and analysis, 2005, 18(8): 771-87.

[15] Biswas S, Prabhu R K, Hussain K J, et al. Heavy metals concentration in edible fishes from coastal region of Kalpakkam, southeastern part of India [J]. Environmental monitoring and assessment, 2012, 184(8): 5097-104. 